\title{
Article
}

\section{Optimization of Propagation Medium for Enhanced Polyhydroxyalkanoate Production by Pseudomonas oleovorans ${ }^{\dagger}$}

\author{
Daniela Chmelová $^{1}$, Barbora Legerská ${ }^{1}$, Miroslav Ondrejovič ${ }^{1, *}$ and Stanislav Miertuš ${ }^{1,2}$ \\ 1 Department of Biotechnology, Faculty of Natural Sciences, University of SS. Cyril and Methodius, J. Herdu 2, \\ SK-917 01 Trnava, Slovakia; daniela.chmelova@ucm.sk (D.C.); barbora.legerska@ucm.sk (B.L.); \\ stanislav.miertus@ucm.sk (S.M.) \\ 2 ICARST n.o., Jamnického 19, SK-841 01 Bratislava, Slovakia \\ * Correspondence: miroslav.ondrejovic@ucm.sk \\ + The paper is dedicated to paying tribute to the memory of Professor Federica Chiellini.
}

check for updates

Citation: Chmelová, D.; Legerská, B.; Ondrejovič, M.; Miertuš, S.

Optimization of Propagation

Medium for Enhanced

Polyhydroxyalkanoate Production by Pseudomonas oleovorans. Fermentation 2022, 8, 16. https://doi.org/10.3390/ fermentation 8010016

Academic Editor: Luísa

Seuanes Serafim

Received: 9 December 2021

Accepted: 29 December 2021

Published: 31 December 2021

Publisher's Note: MDPI stays neutral with regard to jurisdictional claims in published maps and institutional affiliations.

Copyright: (C) 2021 by the authors. Licensee MDPI, Basel, Switzerland. This article is an open access article distributed under the terms and conditions of the Creative Commons Attribution (CC BY) license (https:// creativecommons.org/licenses/by/ $4.0 /)$.

\begin{abstract}
Polyhydroxyalkanoates (PHAs) represent a promising alternative to commercially used petroleum-based plastics. Pseudomonas oleovorans is a natural producer of medium-chain-length PHA (mcl-PHA) under cultivation conditions with nitrogen limitation and carbon excess. Two-step cultivation appears to be an efficient but more expensive method of PHA production. Therefore, the aim of this work was to prepare a minimal synthetic medium for maximum biomass yield and to optimize selected independent variables by response surface methodology (RSM). The highest biomass yield $(1.71 \pm 0.04 \mathrm{~g} / \mathrm{L})$ was achieved in the optimized medium containing $8.4 \mathrm{~g} / \mathrm{L}$ glucose, $5.7 \mathrm{~g} / \mathrm{L}$ sodium ammonium phosphate and $35.4 \mathrm{mM}$ phosphate buffer. Under these conditions, both carbon and nitrogen sources were completely consumed after $48 \mathrm{~h}$ of the cultivation and the biomass yield was 1.7-fold higher than in the conventional medium recommended by the literature. This approach demonstrates the possibility of using two-stage PHA cultivation to obtain the maximum amount of biomass and PHA.
\end{abstract}

Keywords: polyhydroxyalkanoates; Pseudomonas; PHA; optimization

\section{Introduction}

Traditionally used petrochemical-based plastics produced from fossil resources pose a serious problem due to the depletion of fossil resources as well as the accumulation of nondegradable waste in the environment [1-3]. Therefore, the search for a suitable alternative is an important area of research. Microbially synthesized polyhydroxyalkanoates (PHAs) as natural biodegradable polyesters are environmentally sustainable substitutes for commercial plastics $[4,5]$ and have no negative impact on the environment $[6,7]$.

PHAs can be synthesized by a variety of wild-type or genetically modified organisms, including the archaea [8,9], bacteria [10-12], yeasts [13,14] or algae [15,16]. Particularly important producers are bacteria, which typically require a limiting concentration of a single source, such as nitrogen, oxygen, phosphorus, magnesium or sulfur, and an excess of a carbon source for efficient PHA production [17-19]. The genus Pseudomonas is one of these bacterial producers that additionally produces medium-chain-length PHAs (mclPHAs) through two biosynthetic pathways [20]. Each biosynthetic pathway uses a different substrate to produce the 3-HA precursors for mcl-PHA synthesis [21,22]. Fatty acids as aliphatic carbon sources are utilized by these bacteria via fatty acid $\beta$-oxidation, but they are also able to use de novo fatty acid synthesis to synthesize mcl-PHA monomers from unrelated carbon sources such as glucose, gluconate or ethanol [23-25]. Pseudomonas oleovorans produces PHAs containing different mcl monomers $\left(\mathrm{C}_{6}-\mathrm{C}_{12}\right)$ depending on the substrate used [26]; mcl-PHAs have better elastic and flexible properties than other biodegradable polymers [27-29] and are therefore applicable in medical devices, food, agriculture and 
consumer products $[30,31]$. However, high overall production costs, including sterilization costs, as well as low conversion of carbon substrates to PHA remain a challenge for industrial-scale PHA production [32].

A necessary step to produce a sufficient biomass amount of a producer is propagation, leading to the acquisition of a larger amount of product. However, continuous PHA production is a challenge because PHA synthesis is not associated with growth. Therefore, it is not possible to optimize producer growth and PHA production simultaneously. A prerequisite for successful PHA production is a two-step cultivation adapted to the physiological and kinetic specificities of the biological system [33]. The cost of the set-up process can be reduced by appropriately adjusting the culture conditions, the composition of the culture medium and downstream processing [33,34]. First, it is necessary to know the producer's requirements as well as the optimum conditions for the growth and PHA production. In the case of Pseudomonas cultivation, several authors [26,35-38] used a two-step cultivation method to maximize biomass production and subsequently stimulate PHA production. The first phase is the production of bacterial biomass in order to obtain the highest possible density and adjust growth conditions of the producer. The second phase of cultivation involves a nutrient reduction step and is designed to promote PHA accumulation [20,22].

The aim of this study was to prepare a synthetic propagation medium with minimal nutrients in order to maximize the production of P. oleovorans biomass and to optimize the selected independent variables by using response surface methodology (RSM).

\section{Results}

\subsection{Screening the Variable Components Affecting Biomass Production and PHA Yield}

We applied the Plackett-Burman model as a statistical tool for screening the variables affecting biomass production, based on the absence of a selected component of the conventional propagation medium. The effect of the absence of each component on the dependent variables (the consumption of glucose and sodium ammonium phosphate, and the biomass and PHA concentrations) is shown in Figure 1.

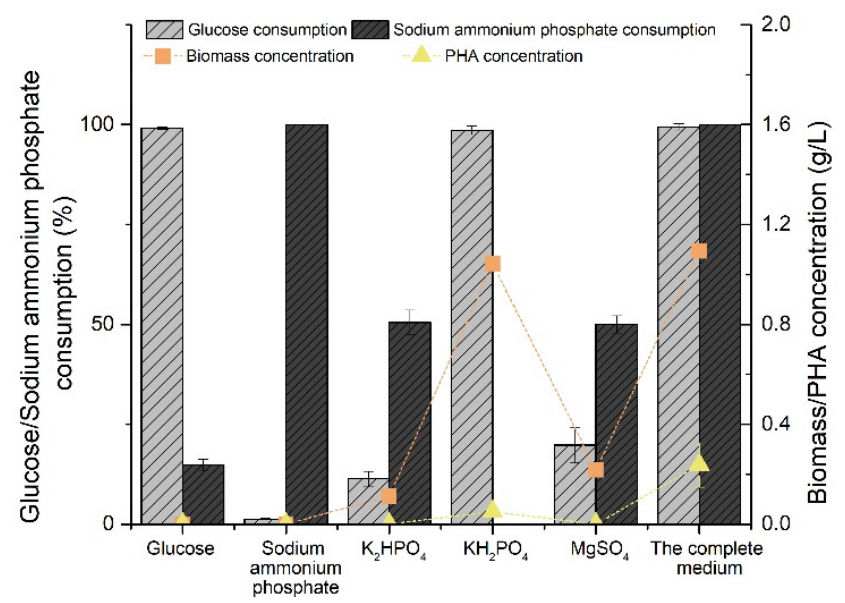

Figure 1. Effect of the absence of the selected component on the propagation medium and the complete propagation medium on the monitored variables.

The absence of any component of the propagation medium decreases biomass and PHA concentrations, except in the absence of $\mathrm{KH}_{2} \mathrm{PO}_{4}$ (Figure 1). Both $\mathrm{C}$ and $\mathrm{N}$ sources were completely or almost completely depleted in the medium without $\mathrm{KH}_{2} \mathrm{PO}_{4}$ and in the complete propagation medium. The biomass concentration in the complete propagation medium was $1.09 \pm 0.02 \mathrm{~g} / \mathrm{L}$ and the PHA concentration was $0.24 \pm 0.09 \mathrm{~g} / \mathrm{L}$. In the absence of $\mathrm{KH}_{2} \mathrm{PO}_{4}$, the biomass concentration was comparable $(1.04 \pm 0.02 \mathrm{~g} / \mathrm{L})$, but PHA concentration decreased to $0.05 \pm 0.00 \mathrm{~g} / \mathrm{L}$. Since $\mathrm{KH}_{2} \mathrm{PO}_{4}$ forms a stable $\mathrm{pH}$ with $\mathrm{K}_{2} \mathrm{HPO}_{4}$ during cultivation and at the same time its presence in the medium has no effect on the biomass concentration, we decided to keep this component in the propagation medium. 
After the end of cultivation, the $\mathrm{pH}$ decreased only minimally (6.64-6.95) from the initial $\mathrm{pH}$ of 7.0. The lowest $\mathrm{pH}$ was measured in the medium without $\mathrm{KH}_{2} \mathrm{PO}_{4}$, namely $6.27 \pm 0.03$ (data not shown). Since we found that the presence of the other components was important, the effect of different concentrations of glucose, sodium ammonium phosphate, magnesium sulfate and molarity of phosphate buffer on the growth of P. oleovorans and PHA production was investigated in further experiments (Figure 2).
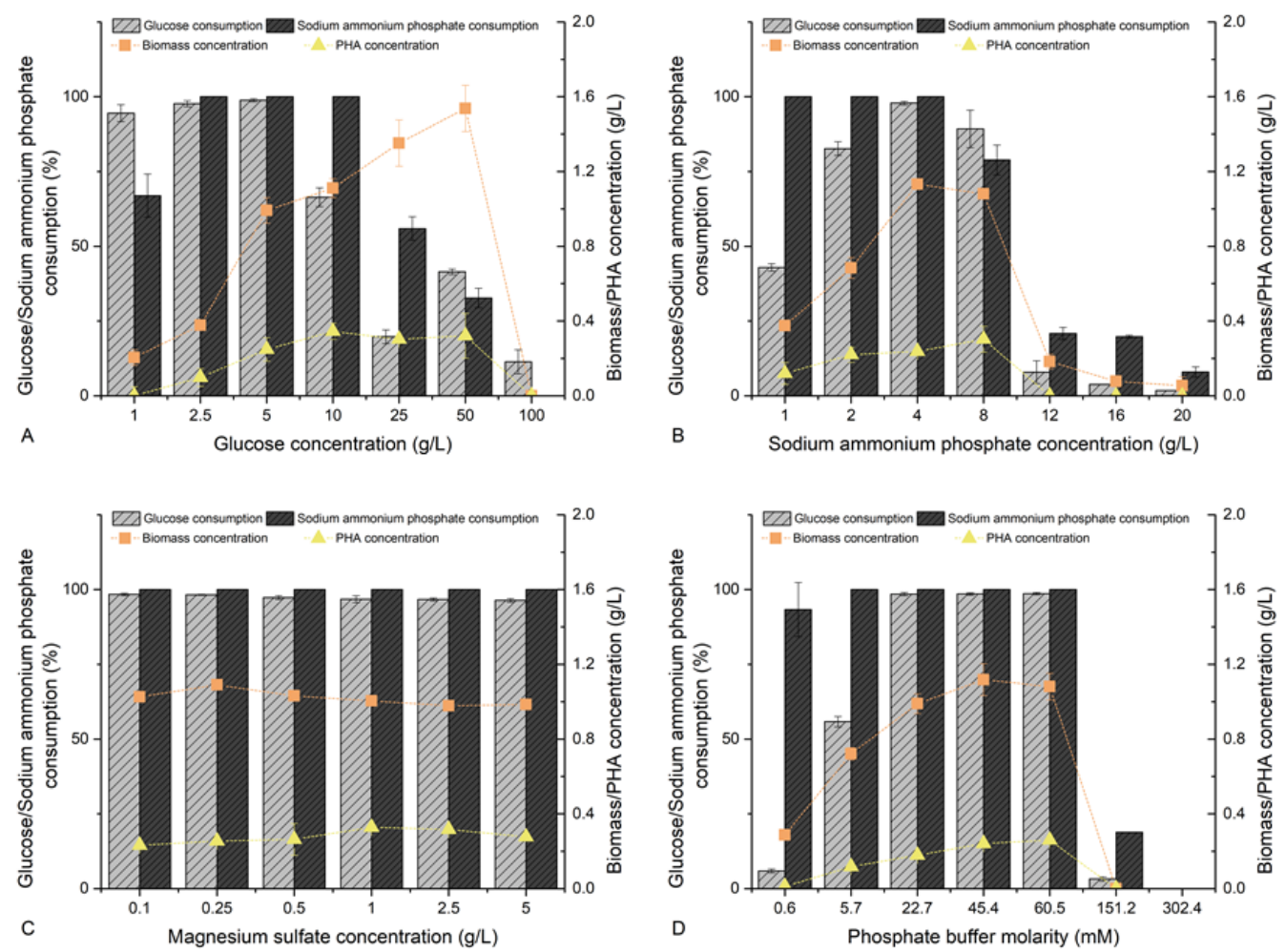

Figure 2. The influence of a selected component of the propagation medium (A) - glucose concentration (g/L); (B)—sodium ammonium phosphate concentration (g/L); (C)—magnesium sulfate concentration $(\mathrm{g} / \mathrm{L})$ and $(\mathbf{D})$ - phosphate buffer molarity $(\mathrm{mM})$ ) on the monitored variables. The concentrations of parameters not investigated in a propagation medium were $5.0 \mathrm{~g} / \mathrm{L}$ glucose, $4.0 \mathrm{~g} / \mathrm{L}$ sodium ammonium phosphate, $0.25 \mathrm{~g} / \mathrm{L} \mathrm{MgSO}_{4} \cdot 7 \mathrm{H}_{2} 0$ and $60.5 \mathrm{mM}$ phosphate buffer.

The concentration of glucose and sodium ammonium sulfate and the concentration of phosphates have a significant effect on biomass growth (Figure 2). The $\mathrm{pH}$ values decreased from 7.0 to 6.6-7.0 after the cultivation (data not shown). Biomass concentration increased with increasing glucose concentration, with the highest biomass concentration $(1.54 \pm 0.12 \mathrm{~g} / \mathrm{L})$ observed with an excess carbon source of $50 \mathrm{~g} / \mathrm{L}$ (Figure 2A). However, the glucose concentration was limiting for the growth of P. oleovorans; further increase of glucose concentration led to a growth inhibition. The PHA concentration was comparable in the range of glucose concentrations from 10 to $50 \mathrm{~g} / \mathrm{L}(\sim 0.32 \pm 0.02 \mathrm{~g} / \mathrm{L})$. As sodium ammonium phosphate concentration increases (Figure 2B), there is an increase in the biomass and PHA yields up to a concentration of $8 \mathrm{~g} / \mathrm{L}$. The highest biomass concentration was measured at $4 \mathrm{~g} / \mathrm{L}(1.13 \pm 0.02 \mathrm{~g} / \mathrm{L})$ and the highest PHA concentration at $8 \mathrm{~g} / \mathrm{L}$ $(0.30 \pm 0.07 \mathrm{~g} / \mathrm{L})$. A positive effect of increasing phosphate buffer molarity on biomass and PHA concentrations was observed only up to a concentration of $45.4 \mathrm{mM}$ (biomass $1.12 \pm 0.09 \mathrm{~g} / \mathrm{L}$ ) (Figure 2D). PHA production was comparable in the phosphate buffer molarity of $22.7-60.5 \mathrm{mM}(0.23 \pm 0.03 \mathrm{~g} / \mathrm{L})$. The influence of magnesium sulfate concentrations $(0.1-5 \mathrm{~g} / \mathrm{L})$ was observed without a significant effect on the growth $(0.98-1.09 \mathrm{~g} / \mathrm{L})$ and production of PHA (0.23-0.33 g/L) (Figure $2 \mathrm{C})$. The concentrations of the components significantly affecting biomass yield together with their interactions were further evaluated using the RSM approach. 


\subsection{RSM Optimization of Production Parameters}

The experiments described above showed that biomass and PHA concentrations were not affected by magnesium sulfate concentrations. Therefore, the effect of parameters such as glucose concentration, sodium ammonium phosphate concentration, phosphate buffer molarity on biomass concentration ( $\mathrm{g} / \mathrm{L}$ ) and glucose consumption (\%) was evaluated using RSM (Table 1). The measured values of biomass concentration were in the range $0.00-1.74 \mathrm{~g} / \mathrm{L}$; glucose consumption varied from 7.4 to $100.0 \%$. The experimental data obtained were used to calculate the coefficients of the second-order polynomial equations (see Methods for further detail).

Table 1. Experimental design with actual and coded level of independent variables and the measured values of biomass concentration $(\mathrm{g} / \mathrm{L})$ and glucose consumption $(\%)$.

\begin{tabular}{|c|c|c|c|c|c|}
\hline Run No. & $\begin{array}{c}\text { Glucose Concentration } \\
(\mathrm{g} / \mathrm{L})\end{array}$ & $\begin{array}{l}\text { Sodium Ammonium } \\
\text { Phosphate } \\
\text { Concentration }(g / L)\end{array}$ & $\begin{array}{c}\text { Phosphate Buffer } \\
\text { Molarity (mM) }\end{array}$ & $\begin{array}{c}\text { Biomass } \\
\text { Concentration }(g / L)\end{array}$ & $\begin{array}{c}\text { Glucose Consumption } \\
(\%)\end{array}$ \\
\hline 1 & $5(-1)$ & $4(-1)$ & $20(-1)$ & $0.94 \pm 0.01$ & $100.0 \pm 0.0$ \\
\hline 2 & $7.5(0)$ & $6(0)$ & $40(0)$ & $1.61 \pm 0.03$ & $99.9 \pm 0.1$ \\
\hline 3 & $10(1)$ & $8(1)$ & $20(-1)$ & $1.35 \pm 0.04$ & $81.9 \pm 0.5$ \\
\hline 4 & 10 (1) & $4(-1)$ & $60(1)$ & $1.11 \pm 0.01$ & $66.2 \pm 2.1$ \\
\hline 5 & $5(-1)$ & $8(1)$ & $60(1)$ & $0.42 \pm 0.08$ & $89.2 \pm 0.6$ \\
\hline 6 & $5(-1)$ & $4(-1)$ & 60 (1) & $0.99 \pm 0.02$ & $100.0 \pm 0.0$ \\
\hline 7 & $5(-1)$ & $8(1)$ & $20(-1)$ & $1.07 \pm 0.02$ & $100.0 \pm 0.0$ \\
\hline 8 & $7.5(0)$ & $6(0)$ & $40(0)$ & $1.56 \pm 0.15$ & $100.0 \pm 0.0$ \\
\hline 9 & $10(1)$ & $8(1)$ & 60 (1) & $0.00 \pm 0.00$ & $7.4 \pm 0.2$ \\
\hline 10 & $10(1)$ & $4(-1)$ & $20(-1)$ & $1.03 \pm 0.02$ & $65.1 \pm 0.2$ \\
\hline 11 & $3.3(-1.682)$ & $6(0)$ & $40(0)$ & $0.86 \pm 0.02$ & $100.0 \pm 0.0$ \\
\hline 12 & $7.5(0)$ & $6(0)$ & $73.5(1.682)$ & $0.00 \pm 0.00$ & $7.5 \pm 1.3$ \\
\hline 13 & $7.5(0)$ & $6(0)$ & $6.5(-1.682)$ & $0.64 \pm 0.00$ & $53.3 \pm 2.1$ \\
\hline 14 & 11.7 (1.682) & $6(0)$ & $40(0)$ & $1.44 \pm 0.01$ & $75.9 \pm 0.8$ \\
\hline 15 & $7.5(0)$ & 9.3 (1.682) & $40(0)$ & $0.89 \pm 0.27$ & $64.1 \pm 0.0$ \\
\hline 16 & $7.5(0)$ & $2.7(-1.682)$ & $40(0)$ & $1.04 \pm 0.19$ & $79.3 \pm 2.1$ \\
\hline 17 & $7.5(0)$ & $6(0)$ & $40(0)$ & $1.74 \pm 0.05$ & $100.0 \pm 0.0$ \\
\hline
\end{tabular}

The $\mathrm{R}^{2}$ coefficients were set at $95.6 \%$ for biomass concentration and $93.7 \%$ for glucose consumption. Three-dimensional graphs for better understanding the interactions between the selected variables are shown in Figure 3.
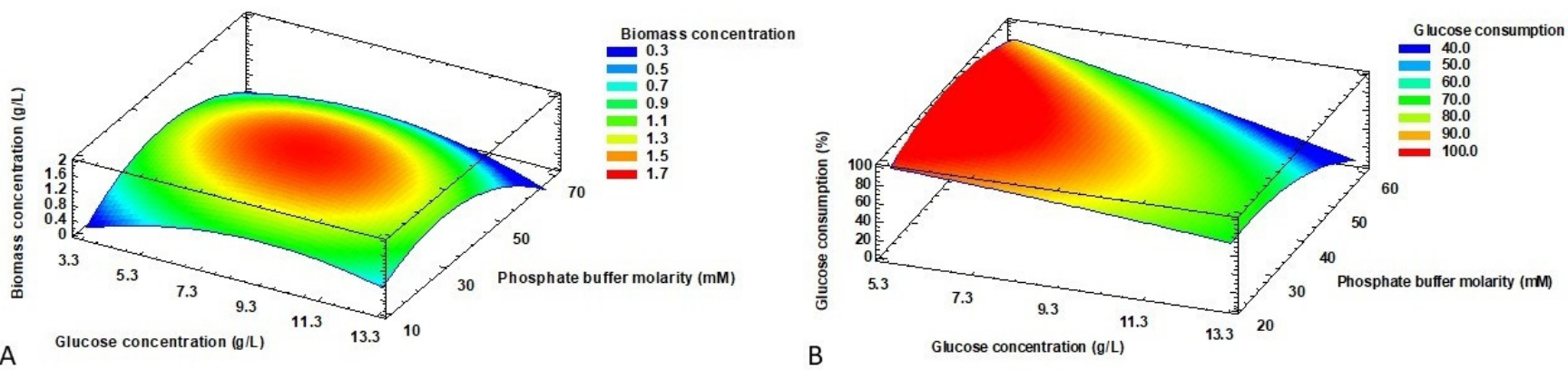

Figure 3. Response surface model plots showing the effects of the phosphate buffer molarity and the glucose concentration on the biomass concentration (A) and the carbon consumption (B). The optimal value of the sodium ammonium phosphate concentration was set as a constant.

Table 2 summarizes the regression coefficients and analysis of variances calculated for the biomass concentration and the glucose consumption. The results show that the increase of the phosphate buffer molarity (from 20.0 to $35.4 \mathrm{mM}$ ) had a significant positive linear effect $(p<0.05)$ on the biomass concentration (Figure 3A). Moreover, quadratic effect of all tested factors (AA, BB and CC) significantly affected the biomass concentration $(p<0.05)$. A significant interaction effect between sodium ammonium phosphate concentration and phosphate buffer molarity was found $(p<0.05)$. Not surprisingly, glucose concentration had a positive linear effect $(p<0.05)$ on glucose consumption. The phosphate buffer molarity 
had a significant positive linear effect $(p<0.05)$ and a negative quadratic effect $(p<0.05)$. As the molarity of the phosphate buffer increases up to $40 \mathrm{mM}$ (Figure 3B), the glucose consumption also increases.

Table 2. Regression coefficients of the predicted second order polynomial models for biomass concentration and glucose consumption.

\begin{tabular}{cccc}
\hline Effect & Factor $^{\mathbf{1}}$ & Biomass Concentration & Glucose Consumption \\
\hline Constant & & -5.37985 & -111.602 \\
\hline \multirow{3}{*}{ Linear } & $\mathrm{A}$ & 0.506695 & $\mathbf{6 . 6 6 7 7 2}$ \\
& $\mathrm{B}$ & 0.921379 & 33.5018 \\
& $\mathrm{C}$ & $\mathbf{0 . 1 3 0 6 8 9}$ & $\mathbf{6 . 4 6 9 1 2}$ \\
\hline \multirow{3}{*}{ Quadratic } & $\mathrm{AA}$ & $\mathbf{- 0 . 0 2 3 7 7}$ & -0.12396 \\
& $\mathrm{BB}$ & $\mathbf{- 0 . 0 5 3 6 6}$ & -1.6428 \\
& $\mathrm{CC}$ & $\mathbf{- 0 . 0 0 1 1 1}$ & $-\mathbf{0 . 0 5 3 3 3}$ \\
\hline \multirow{3}{*}{ Interaction } & $\mathrm{AB}$ & -0.00875 & -0.782 \\
& $\mathrm{AC}$ & -0.00168 & -0.15655 \\
& $\mathrm{BC}$ & $\mathbf{0 . 0 0 6 6 6}$ & -0.27 \\
\hline
\end{tabular}

${ }^{1}$ A-glucose concentration, B-sodium ammonium phosphate concentration and C-phosphate buffer molarity. Statistically significant differences at $p$-value $<0.05$ are shown in bold.

\subsection{Optimization and Verification of the Model}

The optimal cultivation conditions for biomass production by P. oleovorans were determined as follows: $8.4 \mathrm{~g} / \mathrm{L}$ glucose, $5.7 \mathrm{~g} / \mathrm{L}$ sodium ammonium phosphate and $35.4 \mathrm{mM}$ phosphate buffer (Table 3).

Table 3. Predicted and experimentally verified values of biomass concentration and glucose consumption under optimal production conditions.

\begin{tabular}{cccccc}
\hline & Independent Variable & & & \\
\hline $\begin{array}{c}\text { Dependent } \\
\text { Variable }\end{array}$ & Glucose Concentration $(\mathrm{g} / \mathrm{L})$ & $\begin{array}{c}\text { Sodium Ammonium } \\
\text { Phosphate Concentration } \\
(\mathrm{g} / \mathrm{L})\end{array}$ & $\begin{array}{c}\text { Phosphate Buffer } \\
\text { Molarity (mM) }\end{array}$ & $\begin{array}{c}\text { Predicted } \\
\text { Value }\end{array}$ & $\begin{array}{c}\text { Experimental } \\
\text { Value }\end{array}$ \\
\hline $\begin{array}{c}\text { Biomass } \\
\text { concentration }\end{array}$ & 8.4 & 5.7 & 35.4 & $1.68 \mathrm{~g} / \mathrm{L}$ & $1.71 \pm 0.04 \mathrm{~g} / \mathrm{L}$ \\
\hline $\begin{array}{c}\text { Glucose } \\
\text { consumption }\end{array}$ & 7.5 & 6.0 & 40.0 & $100 \%$ & $100 \pm 0.01 \%$ \\
\hline
\end{tabular}

Complete glucose consumption can be achieved under the following optimal conditions: glucose concentration $7.5 \mathrm{~g} / \mathrm{L}$, sodium ammonium phosphate concentration $6.0 \mathrm{~g} / \mathrm{L}$ and phosphate buffer molarity $40.0 \mathrm{mM}$ (Table 3). Under selected optimal conditions, the predicted biomass concentration and glucose consumption should be $1.71 \mathrm{~g} / \mathrm{L}$ and $100 \%$, respectively. We verified the optimal conditions and found that there was no significant statistical difference $(p<0.005)$ between the predicted and experimental values of the dependent variables (Table 3). Moreover, the glucose consumption under optimal conditions for biomass concentration was $98.3 \pm 0.09 \%$, but the biomass concentration under optimal conditions for glucose consumption was $1.49 \pm 0.04 \mathrm{~g} / \mathrm{L}$ (data not shown). However, given the aim of the study, we chose the optimal conditions for biomass concentration. In summary, we achieved a 1.7-fold higher biomass concentration in the optimized propagation medium than in the conventional medium recommended by the literature.

\section{Discussion}

The production of an intracellular metabolite requires a rapid accumulation of biomass, and at the same time, high production of the metabolite in cells. PHA accumulation is initiated by depletion of the essential nutrient, but this is not compatible with high biomass production. Two-step cultivation, possibly fed-batch or continuous cultivation, appears to be an effective way to produce a secondary metabolite [26,35-38]. This study was aimed to 
optimize the propagation medium resulting in maximum biomass yield in the first step of bacterial PHA production. The composition of the propagation medium frequently used in published studies [35-37,39,40] was chosen. The necessity of individual components present in the medium can be verified using a Plackett-Burman design. The results of the first model (data not shown) suggest that the presence of the trace elements commonly used for other PHA producers $[38,41,42]$ is not necessary. The absence of the trace element solution in the propagation medium did not affect the biomass yield. Other authors obtained the same results in their experiments $[38,43,44]$. Even the trace element solution did not affect the PHA yield [43,44]. Subsequently, the second analysis according to the Plackett-Burman statistical model (Figure 1) showed that carbon and nitrogen sources and phosphorus-containing buffer had a significant effect on P. oleovorans growth. Although there are few scientific works focusing on the optimization of the P. oleovorans biomass growth (later name P. oleovorans GPo1, now P. putida or P. pseudoalcaligenes) [45], the results can be compared with other producers of the genus Pseudomonas due to the remarkably close similarity of biosynthetic pathways $[11,20,46,47]$. The frequently used carbon sources for the genus Pseudomonas are mainly various oils and fatty acids [38,48] and phenols [49], but also waste raw materials and wastewaters [48,50]. The choice of $C$ and $N$ sources has a significant impact on biomass yield and PHA production [23,48,51]. However, simple organic carbon sources in suitable concentration such as glucose are used to produce biomass [52,53]. Glucose limitation leads to lower biomass yields due to a bacterial growth reduction [54], as also confirmed by our results (Figure 2c).

The absence of $\mathrm{K}_{2} \mathrm{HPO}_{4}$ in the propagation medium had a negative effect on the biomass and PHA concentrations (Figure 1). The absence of $\mathrm{KH}_{2} \mathrm{PO}_{4}$ had no effect on both monitored variables, although the initial $\mathrm{pH}$ of both propagation media was set to 7.0. The $\mathrm{pH}$ value has a significant effect on biomass and PHA yields $[53,55,56]$. The neutral $\mathrm{pH}$ is most suitable for the genus Pseudomonas due to the highest activity of enzymes involved in PHA synthesis [56]. However, the $\mathrm{pH}$ after cultivation was lower in the medium in the absence of $\mathrm{KH}_{2} \mathrm{PO}_{4}(6.27 \pm 0.03)$ than in the medium without $\mathrm{K}_{2} \mathrm{HPO}_{4}(6.64 \pm 0.02)$. Other media (Figure 1) had $\mathrm{pH}$ in the range 6.84-6.95 (data not shown). Therefore, these results are probably related to the amount of phosphorus in the propagation medium. Protein synthesis increased at high phosphorus concentrations, whereas a phosphate deficiency leads to a reduction in protein synthesis rate and affects biomass and PHA yields [54]. Low phosphorus concentration in $\mathrm{K}_{2} \mathrm{HPO}_{4}$-free medium significantly affected the biomass production of P. oleovorans (Figure 1). Different concentrations of magnesium sulfate (Figure 2C) had no notable effect on either biomass or PHA yield. This conclusion was confirmed in the studies of Nikel et al. [53] and Sangkharak and Prasertsan [54]. The PHA production was approximately $23 \pm 1.7 \%$ (Figure 2 ). In some experiments, specifically when the glucose concentration was increased or the sodium ammonium phosphate concentration was decreased, we obtained $32 \pm 0.7 \%$ of PHAs (Figure 2). These relatively high PHA yields may indicate culture limitation probably due to oxygen limitation. The problem of maintaining oxygen transfer rate associated with high cell density limitation has been described in the literature $[57,58]$. This challenge could be circumvented by the use of oxygen-enriched airflow into the propagation medium in the fermenter.

RSM is a frequently used research method to simultaneously assess the influence of multiple cultivation parameters on PHA production [59-61]. We chose the carbon and nitrogen source concentration and the molarity of phosphate buffer as independent variables in the optimization matrix. Our experimental data confirmed the predicted value of the biomass yield $(1.71 \pm 0.04 \mathrm{~g} / \mathrm{L})$. We observed higher biomass production than the work of Manso Cobos et al. [62]. They cultivated the wild-type bacterial strain of P. pseudoalcaligenes CECT5344 in medium with sodium octanoate $(12.5 \mathrm{mM})$ as carbon source and ammonium chloride $(12.5 \mathrm{mM})$ as nitrogen source with a biomass yield of $1.18 \pm 0.1 \mathrm{~g} / \mathrm{L}$ [62] Prieto et al. [63] achieved a yield of $1.67 \mathrm{~g} / \mathrm{L}$ of genetically modified strain $P$. oleovorans strain GPo1 (xylS/Pm::phaC1- P. oleovorans POMC1). Higher biomass yield can be achieved by changing the $\mathrm{C}$ or $\mathrm{N}$ source, but there are increased production process costs. A two-fold 
increase in biomass yield was observed in the medium using octanoate as a carbon source under optimized P. putida BM01 growth conditions [64]. A comparable increase in biomass yield was also measured in Możejko et al. [52], who cultivated Pseudomonas sp. G101 in medium with glucose and rapeseed oil. These works suggest that the biomass yield can be affected by the ratio $\mathrm{C} / \mathrm{N}$. For the PHA production, the suitable ratio ranges from 5 to 15. The $\mathrm{C} / \mathrm{N}$ ratio is not surprising because PHA production usually starts by an excess of carbon and a lack of nitrogen [52,62-64]. However, lower $\mathrm{C} / \mathrm{N}$ ratios are more suitable for biomass production than higher $\mathrm{C} / \mathrm{N}$ ratios. In our study, we found that the most suitable $\mathrm{C} / \mathrm{N}$ ratio for $P$. oleovorans biomass production is 1.5 . However, biomass production is only the first step, although efficient PHA production requires a sufficient number of cells capable of accumulating intracellular metabolites.

\section{Materials and Methods}

\subsection{Microorganism and Inoculum Preparation}

The bacterial strain Pseudomonas oleovorans DSM 1045 from the DSMZ collection (Deutsche Sammlung von Mikroorganismen und Zellkulturen, Germany) stored at $4{ }^{\circ} \mathrm{C}$ on nutrient agar with 1.0\% (w/v) agar, was used for PHA synthesis. Bacterial cells were reinoculated at 4 -day intervals and cultivated at $30{ }^{\circ} \mathrm{C}$. The cells were diluted with sterile distilled water to obtain 0.8-0.9 McFarland units (MFU) solution and prepared inoculum was used to inoculate the propagation medium at a final concentration of $2 \%(v / v)$.

\subsection{Propagation Medium}

Conventional liquid propagation medium $(20 \mathrm{~mL})$ comprises glucose $(5.0 \mathrm{~g} / \mathrm{L})$; $\mathrm{NaNH}_{4} \mathrm{HPO}_{4} \cdot 4 \mathrm{H}_{2} \mathrm{O}(4.0 \mathrm{~g} / \mathrm{L}) ; \mathrm{K}_{2} \mathrm{HPO}_{4}(5.8 \mathrm{~g} / \mathrm{L}) ; \mathrm{KH}_{2} \mathrm{PO}_{4}(3.7 \mathrm{~g} / \mathrm{L})$ and $\mathrm{MgSO}_{4} \cdot 7 \mathrm{H}_{2} \mathrm{O}$ $(0.25 \mathrm{~g} / \mathrm{L})[29,33,56,57]$ and microelements stock solution $\left(\mathrm{FeSO}_{4} \cdot 7 \mathrm{H}_{2} \mathrm{O}(2.78 \mathrm{~g} / \mathrm{L})\right.$; $\mathrm{MnCl}_{2} \cdot 4 \mathrm{H}_{2} \mathrm{O}(1.98 \mathrm{~g} / \mathrm{L}) ; \mathrm{CoCl}_{2} \cdot 6 \mathrm{H}_{2} \mathrm{O}(4.0 \mathrm{~g} / \mathrm{L}) ; \mathrm{CuCl}_{2} \cdot 2 \mathrm{H}_{2} \mathrm{O}(1.0 \mathrm{~g} / \mathrm{L}) ; \mathrm{CaCl}_{2} \cdot 2 \mathrm{H}_{2} \mathrm{O}(1.67 \mathrm{~g} / \mathrm{L})$; $\mathrm{ZnSO}_{4} \cdot 7 \mathrm{H}_{2} \mathrm{O}(0.29 \mathrm{~g} / \mathrm{L}) ; \mathrm{Na}_{2} \mathrm{MoO}_{4} \cdot 2 \mathrm{H}_{2} \mathrm{O}(2.0 \mathrm{~g} / \mathrm{L}) ; \mathrm{Na}_{2} \mathrm{~B}_{4} \mathrm{O}_{7} \cdot 10 \mathrm{H}_{2} \mathrm{O}(0.23 \mathrm{~g} / \mathrm{L})$; $\mathrm{Al}_{2}\left(\mathrm{SO}_{4}\right)_{3} \cdot 12 \mathrm{H}_{2} \mathrm{O}(1.3 \mathrm{~g} / \mathrm{L})$ in $\left.0.1 \mathrm{~N} \mathrm{HCl}\right)$ mixed with a medium in a ratio of $1: 1000(v / v)[35,36,39,40,65-70]$ was used in the study. Cultivation was performed under dynamic conditions (150 RPM) for $48 \mathrm{~h}$ at $30^{\circ} \mathrm{C}$ and the initial $\mathrm{pH} 7.0$.

\subsection{Growth Pattern}

The growth pattern of $P$. oleovorans was observed in modified propagation medium $(20 \mathrm{~mL})$ (glucose $(5.0 \mathrm{~g} / \mathrm{L}), \mathrm{NaNH}_{4} \mathrm{HPO}_{4} \cdot 4 \mathrm{H}_{2} \mathrm{O}(4.0 \mathrm{~g} / \mathrm{L}), \mathrm{K}_{2} \mathrm{HPO}_{4}(5.8 \mathrm{~g} / \mathrm{L}), \mathrm{KH}_{2} \mathrm{PO}_{4}$ $(3.7 \mathrm{~g} / \mathrm{L})$ and $\left.\mathrm{MgSO}_{4} \cdot 7 \mathrm{H}_{2} \mathrm{O}(0.25 \mathrm{~g} / \mathrm{L})\right)$ under dynamic conditions (150 RPM) for $48 \mathrm{~h}$ at $30{ }^{\circ} \mathrm{C}$ and the initial $\mathrm{pH}$ 7.0. The biomass concentration was determined after drying at $50{ }^{\circ} \mathrm{C}$ to constant weight and the optical density was measured at $600 \mathrm{~nm}$ using a microplate reader (BioTek EL 800, Fisher, Germany). Both variables were determined in propagation media after 14, 18, 20, 22, 24, 32, 36, 42, 44, 46, $48 \mathrm{~h}$ cultivation and the relationship between these two variables was evaluated $\left(\mathrm{y}=0.5693 \mathrm{x}+0.07777 ; \mathrm{R}^{2}=0.95\right)$.

\subsection{Plackett-Burman Design}

The significant variables affecting biomass production were selected using the PlackettBurman design (Table 4) [71]. A total of six variables were tested, and the model was based on the absence of a $(-)$ selected variable. The propagation medium $(20 \mathrm{~mL})$ contained $5 \mathrm{~g} / \mathrm{L}$ glucose, $4 \mathrm{~g} / \mathrm{L}$ sodium ammonium phosphate, $0.25 \mathrm{~g} / \mathrm{L}$ magnesium sulfate, and $60.5 \mathrm{mM}$ phosphate buffer ( $\mathrm{pH} 7.0)$. The cultivation conditions were the same as in the previous experiments. 
Table 4. Plackett-Burman experimental design.

\begin{tabular}{|c|c|c|c|c|c|c|}
\hline \multirow{2}{*}{ Factor } & \multicolumn{6}{|c|}{ Run * } \\
\hline & 1 & 2 & 3 & 4 & 5 & 6 \\
\hline Glucose & - & + & + & + & + & + \\
\hline Sodium ammonium phosphate & + & - & + & + & + & + \\
\hline $\mathrm{K}_{2} \mathrm{HPO}_{4}$ & + & + & - & + & + & + \\
\hline $\mathrm{KH}_{2} \mathrm{PO}_{4}$ & + & + & + & - & + & + \\
\hline $\mathrm{MgSO}_{4} \cdot 7 \mathrm{H}_{2} \mathrm{O}$ & + & + & + & + & - & + \\
\hline
\end{tabular}

* (+) presence or (-) absence of the selected nutrient in the propagation medium.

\subsection{Screening the Components Affecting Biomass Production and PHA Yield}

The effect of glucose (carbon source) concentration (1.0-100.0 g/L), sodium ammonium phosphate (nitrogen source) concentration (1.0-20.0 g/L), magnesium sulfate concentration $(0.1-5.0 \mathrm{~g} / \mathrm{L})$ and phosphate buffer molarity $(0.6-302.4 \mathrm{mM})$ was tested on dependent variables (biomass and PHA concentrations, carbon and nitrogen consumptions).

\subsection{Optimization of Propagation Medium by RSM}

RSM was used to investigate the effect of glucose concentration, sodium ammonium phosphate concentration and phosphate buffer molarity on the dependent variables (biomass concentration and glucose consumption). These three independent factors were tested on five code levels: $-1.682,-1,0,1$ and 1.682 (Table 5).

Table 5. Interpretation of coded levels of the three independent variables tested by RSM.

\begin{tabular}{cccccc}
\hline Variables & \multicolumn{5}{c}{ Code Levels } \\
\cline { 2 - 6 } & $-\mathbf{1 . 6 8 2}$ & $\mathbf{- 1}$ & $\mathbf{0}$ & $\mathbf{1}$ & $\mathbf{1 . 6 8 2}$ \\
\hline $\begin{array}{c}\text { Glucose concentration (g/L) } \\
\text { Sodium ammonium phosphate } \\
\text { concentration (g/L) }\end{array}$ & 3.3 & 5.0 & 7.5 & 10.0 & 11.7 \\
\hline \begin{tabular}{c} 
Phosphate buffer molarity $(\mathrm{mM})$ \\
\hline
\end{tabular} & 6.7 & 4.0 & 6.0 & 8.0 & 9.3 \\
\hline
\end{tabular}

The second-order polynomial function with respect to the three selected parameters is given by Equation (1):

$$
Y=b_{0}+\sum_{i=1}^{k} b_{i} X_{i}+\sum_{i=1}^{k} b_{i i} X_{i}^{2}+\sum_{\substack{i=1 \\ i<j}}^{k-1} \sum_{j=2} b_{i j} X_{i} X_{j}
$$

where $X$ are independent variables (carbon concentration, nitrogen concentration and phosphate buffer molarity), $Y$ is a response (biomass concentration or glucose consumption) and $b$ are regression coefficients. The interaction between two variables and the effect of these factor levels on biomass yield and carbon consumption were derived from 3D surface response plots. The coefficients of the response surface equation were determined.

\subsection{Analytical Methods}

The glucose concentration was determined by the DNS (3,5-dinitrosalicylic acid) method [72] at $540 \mathrm{~nm}$ using a microplate reader. The glucose concentration was expressed as \% of the carbon source consumed during cultivation. The concentration of sodium ammonium phosphate was determined by the Nessler reagent method at $450 \mathrm{~nm}$ using a microplate reader and expressed as \% of nitrogen source consumed during cultivation. The $\mathrm{pH}$ of the propagation medium was determined at the end of cultivation.

The biomass concentration was evaluated using optical density at $600 \mathrm{~nm}$ and expressed in grams per liter of propagation medium. Dried P. oleovorans biomass was homogenized for 5 min at 3000 RPM using metal beads and PHAs were extracted into chloroform 
(15 mL) for $24 \mathrm{~h}$ at $22{ }^{\circ} \mathrm{C}$ and $150 \mathrm{RPM}$. The extract obtained was dried by sodium sulfate, filtered and evaporated to dryness on a rotary evaporator (Heidolph, Germany). The dry extract was washed with $n$-hexane to remove fatty acids, evaporated and the residue represented the crude PHA fraction expressed in grams per liter of propagation medium.

\subsection{Statistical Analysis}

OriginPro 2016 software (OriginLab Corporation, Northampton, MA, USA) was used to process all experimental data obtained. Statgraphic Centurion XV (Statpoint Technologies, Warrenton, Virginia, VA, USA) was used for statistical analysis of experimental data. All assays were performed in triplicate.

\section{Conclusions}

In the present study, we demonstrated that statistical design is an important tool in the preparation of cultivation media. The Plackett-Burman statistical design helped identify the factors needed to produce P. oleovorans biomass. Then, using RSM, we optimized the variables that have the greatest impact on biomass yield, and we were able to increase this amount 1.7 times. The optimal conditions were determined as follows: glucose concentration $8.4 \mathrm{~g} / \mathrm{L}$, sodium ammonium phosphate concentration $5.7 \mathrm{~g} / \mathrm{L}$ and phosphate buffer molarity $35.4 \mathrm{mM}$.

Author Contributions: Conceptualization, D.C. and B.L.; methodology, D.C.; software, D.C.; validation, D.C., B.L. and M.O.; formal analysis, D.C.; investigation, D.C.; resources, M.O.; data curation, D.C.; writing—original draft preparation, D.C. and B.L.; writing—review and editing, M.O. and S.M.; visualization, D.C. and M.O.; supervision, M.O. and S.M.; project administration, M.O.; funding acquisition, S.M. All authors have read and agreed to the published version of the manuscript.

Funding: This research was funded by the Slovak Research and Development Agency, grant numbers APVV-18-0420 and APVV-PP-COVID-20-0010.

Institutional Review Board Statement: Not applicable.

Informed Consent Statement: Not applicable.

Conflicts of Interest: The authors declare that they have no known competing financial interest or personal relationships that could have appeared to influence the work reported in this paper.

\section{References}

1. Pathak, S.; Sneha, C.L.R.; Mathew, B.B. Bioplastics: Its timeline based scenario and challenges. J. Polym. Biopolym. Phys. Chem. 2014, 2, 84-90. [CrossRef]

2. Demeneix, B.A. How fossil fuel-derived pesticides and plastics harm health, biodiversity, and the climate. Lancet Diabetes Endocrinol. 2020, 8, 462-464. [CrossRef]

3. Ford, H.V.; Jones, N.H.; Davies, A.J.; Godley, B.J.; Jambeck, J.R.; Napper, I.E.; Suckling, C.C.; Williams, G.J.; Woodall, L.C.; Koldewey, H.J. The fundamental links between climate change and marine plastic pollution. Sci. Total Environ. 2021, 806, 150392. [CrossRef]

4. Favaro, L.; Basaglia, M.; Casella, S. Improving polyhydroxyalkanoate production from inexpensive carbon sources by genetic approaches: A review. Biofuels Bioprod. Biorefin. 2018, 13, 208-227. [CrossRef]

5. Khatami, K.; Perez-Zabaleta, M.; Owusu-Agyeman, I.; Cetecioglu, Z. Waste to bioplastics: How close are we to sustainable polyhydroxyalkanoates production? Waste Manag. 2021, 119, 374-388. [CrossRef]

6. Dietrich, K.; Dumont, M.-J.; Del Rio, L.F.; Orsat, V. Producing PHAs in the bioeconomy-Towards a sustainable bioplastic. Sustain. Prod. Consum. 2017, 9, 58-70. [CrossRef]

7. Ansari, S.; Sami, N.; Yasin, D.; Ahmad, N.; Fatma, T. Biomedical applications of environmental friendly poly-hydroxyalkanoates. Int. J. Biol. Macromol. 2021, 183, 549-563. [CrossRef]

8. Salgaonkar, B.B.; Bragança, J.M. Utilization of Sugarcane Bagasse by Halogeometricum borinquense Strain E3 for Biosynthesis of Poly(3-hydroxybutyrate-co-3-hydroxyvalerate). Bioengineering 2017, 4, 50. [CrossRef]

9. Salgaonkar, B.B.; Mani, K.; Bragança, J.M. Sustainable Bioconversion of Cassava Waste to Poly(3-hydroxybutyrate-co-3hydroxyvalerate) by Halogeometricum borinquense Strain E3. J. Polym. Environ. 2019, 27, 299-308. [CrossRef]

10. Anjum, A.; Zuber, M.; Zia, K.M.; Noreen, A.; Anjum, M.N.; Tabasum, S. Microbial production of polyhydroxyalkanoates (PHAs) and its copolymers: A review of recent advancements. Int. J. Biol. Macromol. 2016, 89, 161-174. [CrossRef] 
11. Chmelová, D.; Legerská, B.; Ondrejovič, M. Recombinant DNA technology as a tool for improving production of polyhydroxyalkanoates by the natural producers. Nova Biotechnol. Chim. 2020, 19, 124-137. [CrossRef]

12. Xu, Z.; Pan, C.; Li, X.; Hao, N.; Zhang, T.; Gaffrey, M.J.; Pu, Y.; Cort, J.R.; Ragauskas, A.J.; Qian, W.-J.; et al. Enhancement of polyhydroxyalkanoate production by co-feeding lignin derivatives with glycerol in Pseudomonas putida KT2440. Biotechnol. Biofuels 2021, 14, 11. [CrossRef]

13. Rigouin, C.; Lajus, S.; Ocando, C.; Borsenberg, V.; Nicaud, J.M.; Marty, A.; Avérous, L.; Bordes, F. Production and characterization of two medium-chain-length polyhydroxyalkanoates by engineered strains of Yarrowia lipolytica. Microb. Cell Fact. 2019, 18, 99. [CrossRef]

14. Ylinen, A.; Maaheime, H.; Anghelescu-Hakala, A.; Penttilä, M.; Salusjňrvi, L.; Toivari, M. Production of D-lactic acid containing polyhydroxyalkanoate polymers in yeast Saccharomyces cerevisiae. J. Ind. Microbiol. Biotechnol. 2021, 48, kuab028. [CrossRef]

15. Costa, S.S.; Miranda, A.L.; de Morais, M.G.; Costa, J.A.V.; Druzian, J.I. Microalgae as source of polyhydroxyalkanoates (PHAs)—A review. Int. J. Biol. Macromol. 2019, 131, 536-547. [CrossRef]

16. Gradíssimo, D.G.; Xavier, L.P.; Santos, A.V. Cyanobacterial Polyhydroxyalkanoates: A Sustainable Alternative in Circular Economy. Molecules 2020, 25, 4331. [CrossRef]

17. Blunt, W.; Levin, D.B.; Cicek, N. Bioreactor Operating Strategies for Improved Polyhydroxyalkanoate (PHA) Productivity Polymers 2018, 10, 1197. [CrossRef]

18. Madhusoodanan, G.; Hariharapura, R.C.; Somashekara, D. Dissolved oxygen as a propulsive parameter for polyhydroxyalkanoate production using Bacillus endophyticus cultures. Environ. Dev. Sustain. 2021, in press. [CrossRef]

19. Valencia, A.I.S.; Zamora, U.R.; Rodríguez, M.M.; Ramírez, J.; Peláez, M.L.S.; Ortiz, C.F. Effect of C/N ratio on the PHA accumulation capability of microbial mixed culture fed with leachates from the organic fraction of municipal solid waste (OFMSW). J. Water Process. Eng. 2021, 40, 101975. [CrossRef]

20. Mozejko-Ciesielska, J.; Szacherska, K.; Marciniak, P. Pseudomonas Species as Producers of Eco-friendly Polyhydroxyalkanoates. J. Polym. Environ. 2019, 27, 1151-1166. [CrossRef]

21. Muhr, A.; Rechberger, E.M.; Salerno, A.; Reiterer, A.; Malli, K.; Strohmeier, K.; Schober, S.; Mittelbach, M.; Koller, M. Novel Description of mcl-PHA Biosynthesis by Pseudomonas chlororaphis from Animal-Derived Waste. J. Biotechnol. 2013, 165, 45-51. [CrossRef]

22. Blunt, W.; Dartiailh, C.; Sparling, R.; Gapes, D.; Levin, D.B.; Cicek, N. Carbon flux to growth or polyhydroxyalkanoate synthesis under microaerophilic conditions is affected by fatty acid chain-length in Pseudomonas putida LS46. Appl. Microbiol. Biotechnol. 2018, 102, 6437-6449. [CrossRef] [PubMed]

23. Wang, Q.; Nomura, C.T. Monitoring differences in gene expression levels and polyhydroxyalkanoate (PHA) production in Pseudomonas putida KT2440 grown on different carbon sources. J. Biosci. Bioeng. 2010, 110, 653-659. [CrossRef] [PubMed]

24. Wang, Y.; Yin, J.; Chen, G.Q. Polyhydroxyalkanoates, challenges and opportunities. Curr. Opin. Biotechnol. 2014, 30, 59-65. [CrossRef] [PubMed]

25. Moita, R.; Freches, A.; Lemos, P. Crude glycerol as feedstock for polyhydroxyalkanoates production by mixed microbial cultures. Water Res. 2014, 58, 9-20. [CrossRef]

26. Kellerhals, M.B.; Hazenberg, W.; Witholt, B. High cell density fermentation of Pseudomonas oleovorans for the production of mcl-PHAs in two-liquid phase media. Enzym. Microb. Technol. 1999, 24, 111-116. [CrossRef]

27. Basnett, P.; Ching, K.Y.; Stolz, M.; Knowles, J.C.; Boccaccini, A.R.; Smith, C.; Locke, I.C.; Keshavarz, T.; Roy, I. Novel poly(3hydroxyoctanoate)/poly(3-hydroxybutyrate) blends for medical applications. React. Funct. Polym. 2013, 73, 1340-1348. [CrossRef]

28. Takagi, Y.; Yasuda, R.; Yamaoka, M.; Yamane, T. Morphologies and mechanical properties of polylactide blends with medium chain length poly(3-hydroxyalkanoate) and chemically modified poly(3-hydroxyalkanoate). J. Appl. Polym. Sci. 2004, 93, 2363-2369. [CrossRef]

29. Scaffaro, R.; Dintcheva, N.T.; Marino, R.; La Mantia, F.P. Processing and Properties of Biopolymer/Polyhydroxyalkanoates Blends J. Polym. Environ. 2011, 20, 267-272. [CrossRef]

30. Panith, N.; Assavanig, A.; Lertsiri, S.; Bergkvist, M.; Surarit, R.; Niamsiri, N. Development of tunable biodegradable polyhydroxyalkanoates microspheres for controlled delivery of tetracycline for treating periodontal disease. J. Appl. Polym. Sci. 2016, 133, 44128-44140. [CrossRef]

31. Zhang, J.; Shishatskaya, E.; Volova, T.G.; da Silva, L.F.; Chen, G.-Q. Polyhydroxyalkanoates (PHA) for therapeutic applications Mater. Sci. Eng. C 2018, 86, 144-150. [CrossRef] [PubMed]

32. Chen, G.-Q.; Chen, X.-Y.; Wu, F.-Q.; Chen, J.-C. Polyhydroxyalkanoates (PHA) toward cost competitiveness and functionality. Adv. Ind. Eng. Polym. Res. 2020, 3, 1-7. [CrossRef]

33. Koller, M. A Review on Established and Emerging Fermentation Schemes for Microbial Production of Polyhydroxyalkanoate (PHA) Biopolyesters. Fermentation 2018, 4, 30. [CrossRef]

34. Kourmentza, C.; Plácido, J.; Venetsaneas, N.; Burniol-Figols, A.; Varrone, C.; Gavala, H.N.; Reis, M.A.M. Recent Advances and Challenges towards Sustainable Polyhydroxyalkanoate (PHA) Production. Bioengineering 2017, 4, 55. [CrossRef] [PubMed]

35. Du, G.; Yu, J. Metabolic analysis on fatty acid utilization by Pseudomonas oleovorans: Mcl-poly(3-hydroxyalkanoates) synthesis versus $\beta$-oxidation. Process. Biochem. 2002, 38, 325-332. [CrossRef] 
36. Ho, I.C.; Yang, S.P.; Chiu, W.Y.; Huang, S.Y. Structure and polymer form of poly-3-hydroxyalkanoates produced by Pseudomonas oleovorans grown with mixture of sodium octanoate/undecylenic acid and sodium octanoate/5-phanylvaleric acid. Int. J. Biol. Macromol. 2007, 40, 112-118. [CrossRef]

37. da Silva, D.A.; Antonio, R.V.; Rossi, J.M.; Pena, R. Production of medium-chain-length polyhydroxyalkanoate by Pseudomonas oleovorans grown in sugary cassava extract supplemented with andiroba oil. Food Sci. Technol. 2014, 34, 738-745. [CrossRef]

38. Mahato, R.P.; Kumar, S.; Singh, P. Optimization of Growth Conditions to Produce Sustainable Polyhydroxyalkanoate Bioplastic by Pseudomonas aeruginosa EO1. Front. Microbiol. 2021, 12, 711588. [CrossRef]

39. Ashby, R.D.; Solaiman, D.K.Y.; Foglia, T.A. The synthesis of short- and medium-chain-length poly(hydroxyalkanoate) mixtures from glucose- or alkanoic acid-grown Pseudomonas oleovorans. J. Ind. Microbiol. Biotechnol. 2002, 28, 147-153. [CrossRef]

40. Allen, A.D.; Anderson, W.A.; Ayorinde, F.O.; Eribo, B.E. Biosynthesis and characterization of copolymer poly (3HB-co-3HV) from saponified Jatropha curcasoil by Pseudomonas oleovorans. J. Ind. Microbiol. Biotechnol. 2010, 37, 849-856. [CrossRef] [PubMed]

41. Javaid, H.; Nawaz, A.; Riaz, N.; Mukhtar, H.; Haq, I.U.; Shah, K.A.; Khan, H.; Naqvi, S.M.; Shakoor, S.; Rasool, A.; et al. Biosynthesis of Polyhydroxyalkanoates (PHAs) by the Valorization of Biomass and Synthetic Waste. Molecules 2020, 25, 5539. [CrossRef]

42. Dabrowska, D.; Mozejko-Ciesielska, J.; Pokój, T.; Ciesielski, S. Transcriptome Changes in Pseudomonas putida KT2440 during Medium-Chain-Length Polyhydroxyalkanoate Synthesis Induced by Nitrogen Limitation. Int. J. Mol. Sci. 2021, 22, 152. [CrossRef]

43. Nikel, P.I.; Pettinari, J.; Méndez, B.S.; Galvagno, M.A. Statistical optimization of a culture medium for biomass and poly(3hydroxybutyrate) production by a recombinant Escherichia coli strain using agroindustrial byproducts. Int. Microbiol. 2005, 8, 243-250.

44. Sangkharak, K.; Prasertsan, P. Nutrient optimization for production of polyhydroxybutyrate from halotolerant photosynthetic bacteria cultivated under aerobic-dark condition. Electron. J. Biotechnol. 2008, 11, 83-94. [CrossRef]

45. Schoch, C.L.; Ciufo, S.; Domrachev, M.; Hotton, C.L.; Kannan, S.; Khovanskaya, R.; Leipe, D.; McVeigh, R.; O’Neill, K.; Robbertse, B.; et al. NCBI Taxonomy: A comprehensive update on curation, resources and tools. Database 2020, 2020, baaa062. [CrossRef]

46. Diard, S.; Carlier, J.-P.; Ageron, E.; Grimont, P.A.; Langlois, V.; Guérin, P.; Bouvet, O.M. Accumulation of Poly(3-hydroxybutyrate) from Octanoate in Different Pseudomonas Belonging to the rRNA Homology Group I. Syst. Appl. Microbiol. 2002, 25, 183-188. [CrossRef]

47. Mezzina, M.P.; Manoli, M.T.; Prieto, M.A.; Nikel, P.I. Engineering Native and Synthetic Pathways in Pseudomonas putida for the Production of Tailored Polyhydroxyalkanoates. Biotechnol. J. 2021, 16, e2000165. [CrossRef]

48. Pan, L.; Li, J.; Wang, R.; Wang, Y.; Lin, Q.; Li, C.; Wang, Y. Biosynthesis of polyhydroxyalkanoate from food waste oil by Pseudomonas alcaligenes with simultaneous energy recovery from fermentation wastewater. Waste Manag. 2021, 131, 268-276. [CrossRef] [PubMed]

49. Kanavaki, I.; Drakonaki, A.; Geladas, E.D.; Spyros, A.; Xie, H.; Tsiotis, G. Polyhydroxyalkanoate (PHA) production in Pseudomonas sp. phDV1 strain grown on phenol as carbon sources. Microorganisms 2021, 9, 1636. [CrossRef] [PubMed]

50. Getachew, A.; Woldesenbet, F. Production of biodegradable plastic by polyhydroxybutyrate (PHB) accumulating bacteria using low cost agricultural waste material. BMC Res. Notes 2016, 9, 509. [CrossRef] [PubMed]

51. Poblete-Castro, I.; Escapa, I.F.; Jäger, C.; Puchalka, J.; Lam, C.M.C.; Schomburg, D.; Prieto, M.A.; dos Santos, V.A.P.M. The metabolic response of $P$. putida KT2442 producing high levels of polyhydroxyalkanoate under single- and multiple-nutrientlimited growth: Highlights from a multi-level omics approach. Microb. Cell Factories 2012, 11, 34. [CrossRef]

52. Możejko, J.; Wilke, A.; Przybyłek, G.; Ciesielski, S. Mcl-PHAs produced by Pseudomonas sp. Gl01 using fed-batch cultivation with waste rapeseed oil as carbon source. J. Microbiol. Biotechnol. 2011, 22, 371-377. [CrossRef]

53. Zihayat, B.; Shakibaie, M.; Sabouri-Shahrbabak, S.; Doostmohammadi, M.; Ameri, A.; Adeli-Sardou, M.; Forootanfar, H. Medium optimization for polyhydroxyalkanoate production by Pseudomonas pseudoalcaligenes strain Te using D-optimal design. Biocatal. Agric. Biotechnol. 2019, 18, 101001. [CrossRef]

54. Mohan, S.V.; Reddy, M.V. Optimization of critical factors to enhance polyhydroxyalkanoates (PHA) synthesis by mixed culture using Taguchi design of experimental methodology. Bioresour. Technol. 2013, 128, 409-416. [CrossRef]

55. Filipe, C.D.; Daigger, G.T.; Grady, C.L. pH as a key factor in the competition between glycogen-accumulating organisms and phosphorus-accumulating organisms. Water Environ. Res. 2001, 73, 223-232. [CrossRef]

56. Panda, B.; Jain, P.; Sharma, L.; Mallick, N. Optimization of cultural and nutritional conditions for accumulation of poly- $\beta$ hydroxybutyrate in Synechocystis sp. PCC 6803. Bioresour. Technol. 2006, 97, 1296-1301. [CrossRef]

57. Follonier, S.; Henes, B.; Panke, S.; Zinn, M. Putting cells under pressure: A simple and efficient way to enhance the productivity of medium-chain-length polyhydroxyalkanoate in processes with Pseudomonas putida KT2440. Biotechnol. Bioeng. 2012, 109, 451-461. [CrossRef]

58. Horvat, P.; Špoljarić, I.V.; Lopar, M.; Atlić, A.; Koller, M.; Braunegg, G. Mathematical modelling and process optimization of a continuous 5-stage bioreactor cascade for production of poly[-(R)-3-hydroxybutyrate] by Cupriavidus necator. Bioprocess Biosyst. Eng. 2013, 36, 1235-1250. [CrossRef] [PubMed]

59. Saranya, V.; Rajeswari, V.; Abirami, P.; Poornimakkani, K.; Suguna, P.; Shenbagarathai, R. Statistical media design for efficient polyhydroxyalkanoate production in Pseudomonas sp. MNNG-S. Prep. Biochem. Biotechnol. 2015, 46, 446-453. [CrossRef] [PubMed] 
60. Penkhrue, W.; Jendrossek, D.; Khanongnuch, C.; Pathom-Aree, W.; Aizawa, T.; Behrens, R.L.; Lumyong, S. Response surface method for polyhydroxybutyrate (PHB) bioplastic accumulation in Bacillus drentensis BP17 using pineapple peel. PLoS ONE 2020, 15, e0230443. [CrossRef] [PubMed]

61. Trakunjae, C.; Boondaeng, A.; Apiwatanapiwat, W.; Kosugi, A.; Arai, T.; Sudesh, K.; Vaithanomsat, P. Enhanced polyhydroxybutyrate (PHB) production by newly isolated rare actinomycetes Rhodococcus sp. strain BSRT1-1 using response surface methodology. Sci. Rep. 2021, 11, 1896. [CrossRef]

62. Manso Cobos, I.; Ibáñez García, M.I.; de la Peña Moreno, F.; Sáez Melero, L.P.; Luque-Almagro, V.M.; Castillo Rodríguez, F.; Roldán Ruiz, M.D.; Prieto Jiménez, M.A.; Moreno Vivián, C. Pseudomonas pseudoalcaligenes CECT5344, a cyanide-degrading bacterium with by-product (polyhydroxyalkanoates) formation capacity. Microb. Cell Factor. 2015, 14, 77. [CrossRef]

63. Prieto, M.A.; Kellerhals, M.B.; Bozzato, G.B.; Radnovic, D.; Witholt, B.; Kessler, B. Engineering of stable recombinant bacteria for producing of chiral medium-chain-length poly-3-hydroxyalkanoates. Appl. Environ. Microbiol. 1999, 65, 3265-3271. [CrossRef]

64. Song, J.J.; Sung, C.Y. Isolation of Pseudomonas putida BM01 accumulating high amount of PHAMCL. J. Microbiol. Biotechnol. 1994, 4, 126-133.

65. Brandl, H.; Gross, R.A.; Lenz, R.W.; Fuller, R.C. Pseudomonas oleovorans as a source of poly(beta-hydroxyalkanoates) for potential applications as biodegradable polyesters. Appl. Environ. Microbiol. 1988, 54, 1977-1982. [CrossRef] [PubMed]

66. Preusting, H.; Nijenhuis, A.; Witholt, B. Physical characteristics of poly(3-hydroxyalkanoates) and poly(3-hydroxyalkenoates) produced by Pseudomonas oleovorans grown on aliphatic hydrocarbons. Macromolecules 1990, 23, 4220-4224. [CrossRef]

67. Fritzsche, K.; Lenz, R.W.; Fuller, R. Production of unsaturated polyesters by Pseudomonas oleovorans. Int. J. Biol. Macromol. 1990, 12, 85-91. [CrossRef]

68. Kim, Y.B.; Lenz, R.W.; Fuller, R.C. Poly-3-Hydroxyalkanoates containing unsaturated repeating units produced by Pseudomonas oleovorans. J. Polym. Sci. Part A Polym. Chem. 1995, 33, 1367-1374. [CrossRef]

69. Kim, D.Y.; Jung, S.B.; Choi, G.G.; Kim, Y.B.; Rhee, Y.H. Biosynthesis of polyhydroxyalkanoate copolyester containing cyclohexyl groups by Pseudomonas oleovorans. Int. J. Biol. Macromol. 2001, 29, 145-150. [CrossRef]

70. Ashby, R.D.; Solaiman, D.K.Y.; Foglia, T.A. Bacterial Poly(Hydroxyalkanoate) Polymer Production from the Biodiesel Co-product Stream. J. Polym. Environ. 2004, 12, 105-112. [CrossRef]

71. Plackett, R.L.; Burman, J.P. The design of optimum multifactorial experiments. Biometrika 1946, 33, 305-325. [CrossRef]

72. Miller, G.L. Use of Dinitrosalicylic Acid Reagent for Determination of Reducing Sugar. Anal. Chem. 1959, 31, 426-428. [CrossRef] 